\title{
PAWEŁ BORSZOWSKI
}

Uniwersytet Wrocławski

KLAUDIA STELMASZCZYK

Państwowa Wyższa Szkoła Zawodowa w Wałbrzychu

\section{Glosa do wyroku Wojewódzkiego Sądu Administracyjnego w Gdańsku z dnia 17 września 2014 r., I SA/Gd 1632/13}

Teza: Zajęciem na cele działalności gospodarczej gruntu wyłączonego z opodatkowania podatkiem od nieruchomości (gruntu rolnego) będą faktyczne czynności polegające na przeznaczeniu i wykorzystywaniu gruntu do prowadzenia działalności, z zaznaczeniem, że wszelkie działania winny być uzasadnione celami gospodarczymi przedsiębiorcy. Kolejną konieczną przesłanką dla uznania gruntu rolnego za zajętego na potrzeby tej działalności będzie brak możliwości prowadzenia działalności rolnej ${ }^{1}$.

\footnotetext{
1 LEX nr 1533118.
} 


\section{1.}

Glosowany wyrok dotyka jednego z istotniejszych zagadnień w obszarze regulacji przedmiotu opodatkowania podatkiem od nieruchomości w odniesieniu do gruntów. Zagadnienie jest tym bardziej znaczące, iż dotyczy relacji pomiędzy zakresem przedmiotu opodatkowania w trzech podatkach, tj. nie tylko w podatku od nieruchomości ${ }^{2}$, ale również w podatku rolnym ${ }^{3}$ i podatku leśnym ${ }^{4}$. Zależność tę dostrzegł także WSA w Gdańsku w głosowym wyroku, wskazując przy tym odpowiednie sformułowania ustawowe w ustawie o podatku rolnym oraz ustawie o podatku leśnym dotyczące przedmiotu opodatkowania ${ }^{5}$. Związek poprzez przedmiot opodatkowania dotyczy gruntów aż w trzech odrębnych obciążeniach podatkowych, stąd też niezwykle istotne jest właściwe „odczytanie” regulacji ustawowej i jej prawidłowe zastosowanie ze skutkami dla budżetu jednostki samorządu terytorialnego.

WSA w Gdańsku w głosowym wyroku przyjął właściwy pogląd w zakresie rozumienia przepisu art. 2 ust. 2 ustawy o podatkach i opłatach lokalnych. Na aprobatę zasługuje zdefiniowanie zwrotu, którym posłużył się ustawodawca we wskazanym przepisie, co ma niezwykłe znaczenie dla praktyki podatkowej i potwierdza rolę orzecznictwa sądowego w tym zakresie. W glosowanym wyroku WSA potwierdził już wcześniej lansowane w orzecznictwie podatkowym poglądy co do sposobu rozumienia wskazanego zwrotu normatywnego, wskazując także na jeden z takich wyroków w uzasadnieniu ${ }^{6}$.

2 Uregulowanym ustawą z dnia 12 stycznia 1991 r. o podatkach i opłatach lokalnych (tekst jedn. Dz.U. z 2014 r., poz. 849 ze zm., dalej: „ustawa” lub „ustawa o podatkach i opłatach lokalnych").

$3 \quad$ Wprowadzony ustawą z dnia 15 listopada 1984 r. o podatku rolnym (tekst jedn. Dz.U. z 2013 r., poz. 1381 ze zm.).

$4 \quad$ Wprowadzony ustawą z dnia 30 października 2002 r. o podatku leśnym (tekst jedn. Dz.U. z 2013 r., poz. 465 ze zm.).

5 Chodzi o przepis art. 1 ustawy o podatku rolnym oraz art. 1 ust. 1 ustawy o podatku leśnym.

6 Chodzi o wyrok WSA w Lublinie z dnia 24 października 2007 r. sygn. akt I SA/Lu $327 / 07$. 
Nie zasługuje jednak na aprobatę „rozszerzenie”, jakie poczynił WSA w Gdańsku, stosując zwrot normatywny określony w przepisie art. 2 ust. 2 ustawy. Sąd posłużył się bowiem określeniem „zajęcie na cele działalności gospodarczej”, podczas gdy w przepisie art. 2 ust. 2 ustawy o podatkach i opłatach lokalnych ustawodawca posłużył się zwrotem „zajęcie na prowadzenie działalności gospodarczej”. Problem jest o tyle istotny, że dotyka zwrotu normatywnego będącego określeniem nieostrym, a zatem określeniem, które jest przykładem kreowania przez ustawodawcę elastycznego prawa podatkowego. Tworzenie elastycznego prawa podatkowego jest nieuniknione i stanowi swoiste zabezpieczenie przed nadmiarem regulacji prawa podatkowego, także w obszarze unormowania podatków i opłat lokalnych. Tworząc jednakże elastyczne prawo podatkowe, należy podkreślić konieczność zachowania podwyższonego standardu jakości regulacji tego prawa, co ma bezpośrednie odzwierciedlenie także w ramach jego stosowania. Tym bardziej że konsekwencją jego stosowania jest wykreowanie pewnego stopnia elastyczności, co ma niebagatelne znaczenie dla zakreślania obszaru regulacji elastycznego prawa podatkowego.

Tworzenie elastycznego prawa podatkowego powoduje określone konsekwencje w zakresie jego stosowania, co można dostrzec bezpośrednio w ramach głosowanego wyroku. Chodzi bowiem o „właściwy” dobór sformułowań - takich, które odpowiadają zwrotom ustawowym i nie powodują rozszerzenia w stosunku do „wzorca” ustawowego. Takie rozszerzenie powoduje bowiem zwiększenie stopnia elastyczności w stosunku do tego, który zakładał ustawodawca, tworząc dane wyrażenie, co generuje negatywne konsekwencje dla zakresu przedmiotowego opodatkowania. Daje to także niewłaściwy sygnał dla praktyki podatkowej, kiedy stosowanie elastycznego prawa podatkowego powoduje zbytnie rozluźnienie i konieczność poszukiwania obszaru, który nie został przez ustawodawcę wskazany w konkretnym przepisie, tj. w tym przypadku w art. 2 ust. 2 ustawy o podatkach i opłatach lokalnych.

Dlatego też należy poddać wnikliwej analizie użyty zwrot w głosowanym wyroku WSA w Gdańsku w relacji do wyrażenia zawartego w przepisie art. 2 ust. 2 ustawy, by ukazać negatywne konsekwencje, jakie niesie to dla praktyki stosowania prawa podatkowego. 
Ustawodawca podatkowy wprowadzając zwrot, który stał się przedmiotem analizy przez WSA w Gdańsku, kreuje elastyczność, wykorzystując charakterystyczną dla całej konstrukcji podatku od nieruchomości tzw. relację zajęcia ${ }^{7}$. Zwrot ten nie został przez ustawodawcę sprecyzowany w formie definicji legalnej, co podkreślił także sąd w glosowanym wyroku. Ustawodawca zdefiniował bowiem inne wyrażenie także odnoszące się do pewnych skutków prowadzenia działalności gospodarczej ${ }^{8}$, tj. pojęcie gruntów, budynków i budowli związanych z prowadzeniem działalności gospodarczej. Nie wydaje się bowiem konieczne tworzenie przez ustawodawcę podatkowego definicji wszystkich (czy nawet większości) wyrażeń kreujących elastyczność w formie definicji legalnych. Normodawca jest przy tym konsekwentny, gdyż definicji zwrotu odnoszącego się do zajęcia gruntu na prowadzenie działalności gospodarczej nie wprowadza nie tylko w przepisach ustawy o podatkach i opłatach lokalnych, lecz także w przepisach ustawy o podatku rolnym i ustawy o podatku leśnym - co również podkreślał WSA w Gdańsku.

Nie dokonując w tym miejscu szczegółowej oceny stopnia elastyczności wykreowanej przez ustawodawcę poprzez ten zwrot, wypada zauważyć, że ustawodawca „podchodzi” do tego zagadnienia w sposób oszczędny, „zderzając” sformułowanie będące wyrazem pewnego zachowania się podmiotu w sensie zajęcia gruntu z konkretnym przejawem tego zachowania w sensie działalności gospodarczej, a ściślej prowadzenia tej działalności. Prawodawca uzyskuje tym samym niezbędny wyraz precyzji przy tworzeniu elastycznego prawa podatkowego, co jest niezwykle istotne z racji konsekwencji „obserwowanych” przy ocenie stopnia wykreowanej elastyczności. Chodzi więc o ów stopień elastyczności „widziany” poprzez zachowanie się danego podmiotu z wykorzystaniem „substancji gruntu”, gdzie przejaw tego zachowania dotyczy prowadzenia konkretnego rodza-

Relacja ta pojawia się w innych regulacjach tego podatku, jak choćby w przepisie art. 5, czy też w przepisie art. 7 ustawy o podatkach i opłatach lokalnych.

$8 \quad$ Zobacz szerzej na temat podatkowych skutków prowadzenia działalności gospodarczej P. Borszowski, Działalność gospodarcza w konstrukcji prawnej podatku, Warszawa 2010. 
ju działalności gospodarczej, przy czym można tu także rozważać pewien etap początkowy, tj. zachowań podmiotu dotyczących podejmowania działalności gospodarczej z wykorzystaniem gruntu.

WSA w Gdańsku w glosowanym wyroku sformułowanie ustawowe zastosował w taki sposób, iż dodał określenie wskazujące na cel. Przy czym nie wyjaśnił przyczyn takiego zabiegu interpretacyjnego, co może oznaczać, iż analizowany zwrot normatywny ma tożsamy zakres znaczeniowy zarówno dla przypadku, gdy użyjemy go wraz z dodaniem sformułowania wskazującego na cel, jak i dla przypadku bez tego sformułowania. Jednakże analiza tych dwu zwrotów nie pozostawia wątpliwości, że ich zakresy są różne. Sformułowanie wskazujące na zajęcie gruntu na cele działalności gospodarczej oznacza konieczność uwzględnienia konsekwencji wyrażenia odnoszącego się do celu. Warto przy tym zauważyć, że wyrażenie „cel” jest definiowane w różnych dyscyplinach naukowych, przy czym w teorii prawa przyjmuje się, iż cel oznacza postulowany stan rzeczy do którego zmierza określony podmiot ${ }^{9}$. Pojęcie celu wyznacza zatem pewien stan o charakterze postulowanym, do którego należy dążyć, natomiast nie jest to stan, który da się osiągnąć w każdym przypadku, przy czym jest stanem możliwym do osiągnięcia ${ }^{10}$. Jest to więc wyrażenie wskazujące pewien „kierunek działania”. W ramach realizacji celu można podejmować i realizować określone działania, które w większym lub mniejszym zakresie prowadzą do jego osiągnięcia. A zatem posługiwanie się pojęciem celu stanowi duże wyzwanie dla tworzonego w jego następstwie zakresu znaczeniowego, gdzie obok postulowanego stanu rzeczy należy także wyróżnić określone działania - bezpośrednio bądź pośrednio skierowane na jego osiągnięcie - które nie są brane pod uwagę w ramach pojęcia celu.

Uwzględniając więc wprowadzenie terminu wskazującego na cel do relacji zajęcia gruntu na prowadzenie działalności gospodarczej, należy w pierwszej kolejności zauważyć, że otrzymujemy nieczytelny obszar wymagający odniesienia pojęcia celu do relacji zajęcia. Chodzi więc o zachowanie się danego podmiotu, które można kwalifikować w kategoriach

9 I. Bogucka, Funkcje prawa. Analiza pojęcia, Kraków 2000, s. 60.

10 A. Siemianowski, Poznawcze i praktyczne funkcje nauk empirycznych, Warszawa 1979, s. 41. 
zajęcia gruntu w odniesieniu do celu, przy czym ów cel odnieść należy do działalności gospodarczej. Sformułowanie to powoduje de facto nie tylko nieczytelny obszar, lecz nawet brak możliwości stosunkowo ścisłego zakreślenia tego obszaru. Należy bowiem przypomnieć, że ustawodawca użył dość czytelnego sformułowania wskazującego na „relację zajęcia”, poprzez które wymaga konkretnych przejawów zachowań podmiotów. Niestety „zderzenie” owej relacji zajęcia ze sformułowaniem celu powoduje brak możliwości ustalenia w miarę precyzyjnego katalogu takich zachowań. Należałoby bowiem poszukiwać określonych celów działalności gospodarczej i po ich ustaleniu ewentualnie analizować, czy konkretne działania są podejmowane, czy też realizowane dla osiągnięcia danego celu. Ponadto należy zauważyć, że konkretne działania mogą w różnym zakresie realizować założony cel, tj. w sensie zarówno bezpośrednim, jak i pośrednim. Powoduje to zatem „,wymykanie się” obszaru zachowań, do których odsyła ustawodawca w przepisie art. 2 ust. 2 ustawy.

Kolejny problem wynika z odniesienia przez WSA w Gdańsku sformułowania celu do działalności gospodarczej. W konstrukcji podatku od nieruchomości ustawodawca posługuje się definicją działalności gospodarczej, przenosząc w przeważającym zakresie ${ }^{11}$ definicję z art. 2 ustawy o swobodzie działalności gospodarczej ${ }^{12}$. W ramach badanego sformułowania ustawodawca odnosi więc relację zajęcia gruntu do prowadzenia działalności gospodarczej (także jej podejmowania), co oznacza zastosowanie pojęcia działalności gospodarczej, a nie jej celu. W takim bowiem przypadku może powstać co najmniej wątpliwość, czy ustalając zakres wymaganych zachowań, należy badać zarówno pojęcie działalności gospodarczej, jak i jej cel, czy też odrębnie oba terminy, czy też może sam cel i jedynie odnieść „uzyskany wynik” do pojęcia działalności gospodarczej.

11 Zgodnie z przepisem art. 1a ust. 1 pkt 4 ustawy o podatkach i opłatach lokalnych przy pojęciu działalności gospodarczej należy uwzględnić przepis art. 2 ustawy o swobodzie działalności gospodarczej. Przy czym wyjątek wprowadza ustawodawca w przepisie art. 1a ust. 2 ustawy o podatkach i opłatach lokalnych wskazując jakie rodzaje działalności nie należy kwalifikować do działalności gospodarczej w obszarze zastosowania ustawy o podatkach i opłatach lokalnych.

12 Ustawa z dnia 2 lipca 2004 r. o swobodzie działalności gospodarczej (tekst jedn. Dz.U. z 2013 r., poz. 672 ze zm.). 


\section{3.}

Posługiwanie się sformułowaniem zajęcia gruntu na cele prowadzenia działalności gospodarczej w stosunku do określenia ustawowego z art. 2 ust. 2 ustawy o podatkach i opłatach lokalnych powoduje wykreowanie zbyt dużego stopnia elastyczności. Należy bowiem zauważyć, że po pierwsze takiego stopnia elastyczności nie zakładał sam ustawodawca podatkowy, formułując przepis art. 2 ust. 2 ustawy z wykorzystaniem zwrotu uelastyczniającego tekst ustawy, po drugie zaś negatywne konsekwencje powstają dla ustalenia przedmiotu opodatkowania w odniesieniu do gruntu.

Jeżeli zatem chodzi o wykreowanie stopnia elastyczności niezgodnie z założeniem ustawodawcy należy podkreślić, iż uzasadnieniem dla posłużenia się w przepisie art. 2 ust. 2 ustawy analizowanym zwrotem było objęcie zakresem przedmiotowym opodatkowania podatkiem od nieruchomości tych gruntów, które poprzez ich sklasyfikowanie w ewidencji gruntów i budynków podlegałyby innym obciążeniom podatkowym. Stąd też zwrot ten — „relację zajęcia” - wyraża ustawodawca stosunkowo zwięźle, odnosząc ją do konkretnych przejawów zachowań w ramach prowadzenia ${ }^{13}$ działalności gospodarczej. Dostrzegł to także WSA w Gdańsku, wskazując na „(...) faktyczne czynności polegające na przeznaczeniu i wykorzystywaniu gruntu do prowadzenia działalności (...)”. A zatem zakładany przez ustawodawcę stopień elastyczności odpowiada konkretnym czynnościom realizowanym przez podmiot w odniesieniu do gruntu, które to czynności są bezpośrednio kwalifikowane poprzez zakres pojęcia działalności gospodarczej. Poprzez dodanie sformułowania odnoszącego się do celu, uzyskujemy w praktyce zakres zachowań także pośrednio kwalifikowanych pojęciem działalności gospodarczej - co jak już stwierdzono - jest konsekwencją znaczenia pojęcia „cel”. Przyjmując zatem określenie proponowane przez WSA w Gdańsku, musimy zaakceptować taki stopień elastyczności, który pozwala objąć zakresem analizowanego zwrotu nie tylko konkretne przejawy zachowań w ramach prowadzenia działalności gospodarczej. Warto przy tym zauważyć, iż sąd starał się jednak doprecyzować zastosowane

\footnotetext{
13 Przy czym jak już ustalono można to sformułowanie traktować szerzej, odnosząc je do etapu podjęcia i wykonywania tej działalności.
} 
wyrażenie, stwierdzając jednocześnie, że „wszelkie działania winny być uzasadnione celami gospodarczymi przedsiębiorcy (...)”. Niestety. taki zabieg interpretacyjny nie tylko nie rozwiewa wątpliwości ani nie powoduje ograniczenia stopnia elastyczności, lecz wprowadza kolejne trudności interpretacyjne. Wystarczy bowiem zauważyć konieczność ustalenia pojęcia celów gospodarczych podmiotu, relacji tego pojęcia do celów działalności gospodarczej, a przede wszystkim relacji do sformułowania przyjętego w art. 2 ust. 2 ustawy o podatkach i opłatach lokalnych. Ponadto należy zauważyć, iż WSA posługuje się w tym przypadku pojęciem przedsiębiorcy, które to pojęcie nie jest wykorzystywane przez ustawodawcę w ramach konstrukcji art. 2 ust. 2 ustawy o podatkach i opłatach lokalnych.

Wykreowanie zbyt dużego stopnia elastyczności powoduje przede wszystkim negatywne konsekwencje w zakresie ustalenia zakresu przedmiotowego opodatkowania w odniesieniu do gruntu. Chodzi o nieuzasadnione rozszerzenie zakresu przedmiotu opodatkowania podatkiem od nieruchomości, kosztem opodatkowania podatkiem rolnym czy podatkiem leśnym. Kwalifikowanie w obszarze przedmiotu opodatkowania w odniesieniu przykładowo do gruntu sklasyfikowanego jako użytek rolny zachowań, które „wychodzą” poza konkretne przejawy prowadzenia działalności gospodarczej, będąc nakierowane celami określonej działalności gospodarczej, powoduje przesuwanie się zakresu przedmiotu opodatkowania podatkiem od nieruchomości. Biorąc zaś pod uwagę możliwość formułowania różnych celów danego podmiotu, także o charakterze długookresowym, powoduje to brak możliwości ustalenia granicy dla „momentu przesunięcia” zakresu przedmiotu opodatkowania.

\section{4.}

Glosowany wyrok jest bardzo dobrym przykładem stosowania elastycznego prawa podatkowego, a przede wszystkim trudności, jakie powoduje ono w praktyce podatkowej. Formułowanie zakresu znaczeniowego zwrotów uelastyczniających tekst prawny jest jednym z najtrudniejszych problemów funkcjonowania prawa podatkowego. To zadanie spoczywa niewątpliwie w głównej mierze na sądownictwie administracyjnym. Stąd też pozytyw- 
nie należy ocenić zabieg dokonany przez WSA w Gdańsku, gdzie sąd ten definiuje użyty przez ustawodawcę zwrot w przepisie art. 2 ust. 2 ustawy o podatkach i opłatach lokalnych. Formułowanie jednakże zakresu znaczeniowego danego zwrotu uelastyczniającego należy w każdym przypadku dokonywać z założeniem wykreowania takiego stopnia elastyczności, który zakładał sam ustawodawca podatkowy, tworząc daną regulację. W tym więc zakresie należy postulować większą ostrożność w formułowaniu w praktyce podatkowej wyrażeń będących konsekwencją zastosowania elastycznego prawa podatkowego.

\section{Bibliografia:}

Bogucka I., Funkcje prawa. Analiza pojęcia, Zakamycze, Kraków 2000.

Borszowski P., Działalność gospodarcza w konstrukcji prawnej podatku, Wolters Kluwer, Warszawa 2010.

Siemianowski A., Poznawcze i praktyczne funkcje nauk empirycznych, PWN, Warszawa 1979. 